genesis of ulcerative colitis. ${ }^{12-13}$ It should not need stating that ulcerative colitis is a chronic debilitating illness characterised by episodic bloody diarrhoea; many patients suffer faecal incontinence, some require surgical intervention, and some are at increased risk of colon cancer. That such patients have a tendency to neuroticism and introversion is, perhaps, not surprising.

We would not wish to discourage the detailed psychological assessment of patients with ulcerative colitis, but this will only improve our understanding of disease pathogenesis if undertaken in the setting of appropriately controlled clinical trials. Further uncontrolled observations would be at best unhelpful and at worst strengthen an already well established bias.

$S$ A RILEY

M J GOODMAN

Hope Hospital, Leigh Infirmary, and Bury General Hospital, Manchester

1 Paulley JW. Ulcerative colitis: a study of 173 cases. Gastroenterology 1959; 16: 566-76.

2 Paulley JW, Pelser HE. Psychological managemen for psychosomatic disorders. Heidelberg: Springe Verlag, 1989: 70-81.

3 Groen J. Psychogenesis and psychotherapy of ulcerative colitis. Psychosom Med 1947; 9: 151 74.

4 Engel GL. Studies of ulcerative colitis. III. The nature of the psychologic process. Am $\mathcal{F} \mathrm{Med}$ 1955; 19: 231-56.

5 Feldman F, Cantor D, Soll S, Bachrach W. Psychiatric study of a consecutive series of 34 patients with ulcerative colitis. Br Med F 1967 iii: $14-17$.

6 Mendeloff AL, Monk M, Siegel CI, Lilienfeld A Illness experience and life stresses in patients with irritable colon and with ulcerative colitis. NEngl F Med 1970; 282: 14-7.

7 Elser MD, Goulston KJ Levels of anxiety in colonic disorders. $N$ Engl $\mathcal{F}$ Med 1973; 288: 1620

8 Helzer JE, Stillings WA, Chammas S, Norland CC, Alpers DH. A controlled study of the association between ulcerative colitis and psychiatric diagnosis. Dig Dis Sci 1982; 27: 513-8.

9 Paykel ES, Prussoff BA, Uhlenhuth EH. Scaling of life events. Arch Gen Psychiatry 1971; 25 340-7

10 Kearns NP, Cruikshank CA, McGuigan KJ, Riley SA, Shaw SP, Snaith RP. A comparison of depression rating scales. Br $\mathcal{F}$ Psychiatry 1982 141: 45-9.

11 Zigmond AS; Snaith RP. The hospital anxiety and depression scale. Acta Psychiatr Scand 1983; 67: 361-70.

12 McMahon AW, Schmitt P, Paterson SF, Roth man E. Personality differences between inflammatory bowel disease patients and their healthy matory bowel disease patients and their healt

13 Robertson DAF, Ray J, Diamond I, Edwards JG. Personality profile and effective state of patient with inflammatory bowel disease. Gut 1989; 30: 623-6.

\section{Enteropathy associated with HIV}

SIR, - We read with interest the study by Cummins et al (Gut 1990; 31: 317-21) on the enteropathy associated with HIV infection. There is a growing body of evidence for small bowel pathology in patients infected with the human immunodeficiency virus (HIV), and there is broad agreement that atrophy of villi is characteristic of such enteropathy.' Furthermore, there is evidence that jejunal mucosa pathology has functional importance in that reduced fat absorption correlates with the degree of villous atrophy. ${ }^{2}$

There are, however, conflicting reports on the changes in crypt cell proliferation in association with such villous atrophy. The paper by Cummins et al reports jejunal crypts of normal length, but with increased mitotic rate, in HIV infected patients. This is in general agreement with our own findings. ${ }^{1}$ As Cummins et al reiterate, we found a broad spread in crypt length in our patients, ranging from hypoplastic (in one patient with AIDS) through normality to hyperplastic. However the mean jejunal crypt length in our total of 20 HIV infected patients suggested hyperplasia. Notably, we found a strong correlation be tween the degree of atrophy of villi and the degree of hyperplasia of crypts, and faced with these data it is difficult to avoid the conclusion that there may be a causal (rather than coincidental) relation between these two variables.

It is well recognised that enteric infection may induce hyperplastic villous atrophy, and no doubt the dynamics of HIV enteropathy are complicated by opportunistic infections (even, possibly, with as yet unrecognised pathogens). Ullrich $e a^{4}$ have attempted to unravel the two and have described an HIV specific hypoplastic enteropathy, masked in some patients by the crypt hyperplasia induced by secondary pathogens. We quantified hyperplastic HIV enteropathy also in the absence of indentifiable opportunistic infections, but the paper by Cummins et al fails to exclude the effects of other pathogens.

Clearly, the mechanisms underlying the villous atrophy of HIV enteropathy remain elusive and are likely to be multifactorial. Its clarification may have to await an in vitro or animal model of HIV infection, when complicating factors can be carefully controlled.

P A BATMAN

Department of Histopathology, Bradford Royal Infirmary M S KAPEMBWA G E GRIFFIN

Department of Communicable Diseases St George's Hospital Medical School, London

1 Batman PA, Miller ARO, Forster SM, Harris JRW, Pinching AJ, Griffin GE. Jejunal enteropathy associated with human immunodeficiency pathy associated with human immunodeficiency virus infection: quantitat

2 Miller ARO, Griffin GE, Batman P, et al. Jejuna mucosal architecture and fat absorption in male homosexuals infected with human immunodeficiency virus. $Q \mathcal{F}$ Med 1988; 69: 1009-19.

3 Cunningham A, Grohman G, Harkness J, et al. Gastrointestinal viral infections in homosexual men who were symptomatic and sero-positive fo human immunodeficiency virus. F Infect Dis 1988; 158: 386-91.

4 Ullrich R, Zeitz M, Heise W, L'Age M, Hoffken G, Riecken EO. Small intestinal structure and function in patients infected with human immunodeficiency virus (HIV): evidence for HIV nodeficiency virus (HIV): evidence for HIV-
induced enteropathy. Ann Intern Med 1989; 111: induced.

\section{Reply}

SIR, - We thank Batman and colleagues, for commenting on our paper. Both ourselves' and Ullrich $e t a l^{2}$ have described villous atrophy and impaired crypt hyperplasia of the small intestine in HIV infection, particularly in patients with AIDS related complex or AIDS. Ullrich $e$ al further found crypt hypoplasia in AIDS subjects who did not have enteric infections. Batman $e t a l^{3}$ have argued that the enteropathy of HIV infection has crypt hyperplasia, as they found a correlation of crypt length and villous atrophy, although they could show no difference in crypt length. We nevertheless argue that the enteropathy associated with HIV infection is a different pattern to that seen in other enteropathies, as perhaps best exemplified by coeliac disease in which crypt hyperplasia is clearly discernible both by increased crypt length and increased mitotic count per crypt. One explanation for these data could be that some crypt hyperplasia occurs in HIV infection that has not yet progressed to AIDS related complex or AIDS, especially in response to enteric infections. As CD4 lymphocyte depletion occurs systemically and mucosally, the immune 'drive' for crypt proliferation is increasingly impaired. Longitudinal studies will help to confirm such an interpretation.

$$
\begin{array}{r}
\text { A G CUMMINS } \\
\text { J T LaBROOY } \\
\text { D J C SHEARMAN } \\
\text { Queen Elizabeth Hospital, } \\
\text { Woodville South, } \\
\text { South Australia 501I }
\end{array}
$$

Cummins AG, LaBrooy JT, Stanley DP, Rowland $R$, Shearman DJC. Quantitative histological study of enteropathy associated with HIV infection. Gut 1990; 31: 317-21.

2 Ullrich R, Zeitz M, Heise W, L'Age M, Höffken $G$, Riecken EO. Small intestinal structure and function in patients infected with human immunodeficiency virus (HIV): evidence for HIV induced enteropathy. Ann Intern Med 1989; 111 15-21

3 Batman PA, Miller ARO, Forster SM, Harris JRW, Pinching AJ, Griffin GE. Jejunal enteropathy associated with human immunodeficiency virus infection: quantitative histology. $\mathcal{f}$ Clin Pathol 1989; 42: 275-81.

\section{NOTES}

\section{Falk Symposia, 1990}

These will take place in Freiburg, West Germany as follows:

8-10 Oct Hepatic metabolism

11-13 Oct Bile acids as therapeutic agents

15-17 Oct Mechanisms of peptic ulcer healing

18-20 Oct Inflammatory bowel diseases

Further information: Falk Foundation eV Leinenweberstrasse 5, Postfach 6529, D-7800 Freiburg, West Germany.

\section{Endoscopy workshop}

The Chinese Society of Digestive Endoscopy, C.M.A. and the Hong Kong Society of Digestive Endoscopy will be holding the International Workshop and Symposium on Therapeutic Endoscopy and Gastroenterology on 9-12 October 1990 in Beijing, China.

Further details: Dr Joseph Leung, Department of Medicine, Prince of Wales Hospital, Shatin NT, Hong Kong. Tel: (852)6363128/5; Fax: (852)-6350075.

\section{Sir Francis Avery Jones BSG Research Award 1991}

Applications are invited by the Education Committee of the British Society of Gastroenterology who will recommend to Council the recipient of the 1991 Award. Applications (15 copies) should include:

(1) a manuscript (2 A4 pages only) describing the work conducted;

(2) a bibliography of relevant personal publications;

(3) an outline of the proposed content of the lecture, including title;

(4) a written statement confirming that all or a substantial part of the work has been personally conducted in the United Kingdom or Eire.

The Award consists of a medal and a $£ 100$ prize. Entrants must be 40 years or less on 31 December 1991 but need not be a member of the BSG. The recipient will be required to deliver a 40 minute lecture at the Spring Meeting of the Society in Manchester in 1991. Applications (15 copies) should be made to: The Honorary Secretary, BSG, 3 St Andrew's Place, Regent's Park, London NW1 4LB by 1 December 1990. 